\title{
Heat of Combustion and Heat of Formation of Aluminum Carbide
}

\author{
R. C. King and G. T. Armstrong
}

(August 14, 1964)

\begin{abstract}
The heat of combustion of aluminum carbide $\left(\mathrm{Al}_{4} \mathrm{C}_{3}\right)$ in oxygen was measured by means of bomb calorimetry. The solid product of the combustion consisted of alpha aluminum oxide and another crystalline form of alumina, which was characterized as delta alumina. The heats of combustion were corrected for the formation of the delta aluminum oxide. The results, when combined with the heats of formation of alpha aluminum oxide and carbon dioxide, yielded $-49.7 \mathrm{kcal} \mathrm{mole} \mathrm{e}^{-1}$ for the standard heat of formation of aluminum carbide at $298.15^{\circ} \mathrm{K}$ with an estimated overall uncertainty of $\pm 1.2 \mathrm{kcal} \mathrm{mole}^{-1}$.
\end{abstract}

\section{Introduction}

Although several thermodynamic studies have been made on $\mathrm{Al}_{4} \mathrm{C}_{3}$, which is a very stable refractory compound, there exist very few data on the heat of formation. We have, therefore, determined the heat of combustion in oxygen (reaction 1), and have derived the heat of formation.

$$
\mathrm{Al}_{4} \mathrm{C}_{3}(\mathrm{~s})+6 \mathrm{O}_{2}(\mathrm{~g})=2 \mathrm{Al}_{2} \mathrm{O}_{3}(\mathrm{~s})+3 \mathrm{CO}_{2}(\mathrm{~g}) .
$$

We believe that the most reliable previous study was that of Meichsner and Roth [1] $]^{1,2}$, who also determined the heat of combustion in oxygen by bomb calorimetry. For reaction (1) they reported $\Delta H_{293}=-1047.6 \pm 3 \mathrm{kcal} \mathrm{mole}^{-1}$. In a parallel series of experiments they determined the heat of combustion of aluminum, for which they reported $\Delta H_{293}=-392.4 \pm 0.4 \mathrm{kcal}$ mole ${ }^{-1}$. They calculated $\Delta H f^{\circ}{ }_{293}\left[\mathrm{Al}_{4} \mathrm{C}_{3}\right]=-20 \pm 3 \mathrm{kcal} \mathrm{mole}{ }^{-1}$.

The heat of combustion of aluminum is very important in establishing the heat of formation of $\mathrm{Al}_{4} \mathrm{C}_{3}$ by this method, because of the presence of aluminum oxide in the products. In the work of Meichsner and Roth it is given added weight by the fact that the latter authors mixed their $\mathrm{Al}_{4} \mathrm{C}_{3}$ with aluminum powder in order to obtain complete combustion. A significant fraction of the total heat they observed was due to the combustion of the free aluminum. The value of the heat of formation of $\mathrm{Al}_{4} \mathrm{C}_{3}$ calculated from their work is therefore very sensitive to the value selected for the heat of formation of $\mathrm{Al}_{2} \mathrm{O}_{3}$.

As a result of later work on the combustion of aluminum, Roth [2] modified the calculations of Meichsner and Roth and obtained $-40 \mathrm{kcal} \mathrm{mole}^{-1}$ for the heat of formation of $\mathrm{Al}_{4} \mathrm{C}_{3}$. If one assumes that the aluminum oxide in their product was

\footnotetext{
${ }^{1}$ Figures in brackets indicate the literature references at the end of this paper. ${ }^{2}$ After completion of this manuscript, Mah [40] reported a value for the heat of formation of aluminum carbide, which was also obtained by means of oxygen bomb calorimetry. The value reported for $\Delta \mathrm{Hf}^{\circ}{ }_{298.15}\left[\mathrm{Al}_{4} \mathrm{C}_{3}\right]$ is $-53.4 \pm 2.0$ kcal mole -1 .
}

corundum $\left(\alpha-\mathrm{Al}_{2} \mathrm{O}_{3}\right)$, and if a recent value for its heat of formation, $-400.4 \pm 0.3 \mathrm{kcal} \mathrm{mole}^{-1}[3]$, is used in recalculating their data, a value of -48.6 kcal mole ${ }^{-1}$ is obtained for $\Delta H f^{\circ}{ }_{298}\left[\mathrm{Al}_{4} \mathrm{C}_{3}\right]$. However, because Meichsner and Roth determined the heat of combustion of aluminum under nearly the same conditions as those under which they determined the heat of combustion of aluminum carbide, it now seems to us that little can be done to improve the calculation they made in their original publication. The principal difficulty in the way of making any further refinement of their original data now seems to be the lack of any detail about the form of $\mathrm{Al}_{2} \mathrm{O}_{3}$ found in the product. They assumed the $\mathrm{Al}_{2} \mathrm{O}_{3}$ to be corundum, but mention no test of their assumption. Because of the presence of a carbonaceous promoter in their reactions, the presence of another form must now be assumed on the basis of the findings described in this paper.

Our work differs from that of Meichsner and Roth in (1) the exclusion of carbonaceous combustion aids from the reaction, (2) the absence of elemental aluminum as a combustion promoter, (3) the absence of water in the combustion bomb, (4) the unambiguous determination of the amount of reaction by measurement of the mass of $\mathrm{CO}_{2}$ formed, and (5) the identification of the crystal forms of the solid combustion product.

The heat of combustion of aluminum carbide has also been measured, and the heat of formation calculated by Berthelot [4], Wöhler and Hofer [5], and Kameyama and Yoshida [6]. The values they reported for the heat of reaction (1) and the heat of formation of $\mathrm{Al}_{4} \mathrm{C}_{3}$ which we have recalculated on the basis of the recent value for $\mathrm{Al}_{2} \mathrm{O}_{3}$ were, respectively, in kcal mole ${ }^{-1}$ : Berthelot, -824, - 258.9; Wöhler and Hofer, -825.1, - 257.8; Kameyama and Yoshida, - 991.8, - 91.2. These measurements were all made on aluminum carbide samples of relatively low purity. Because of this their work is not considered further, although Kameyama and Yoshida used great care in documenting their measurements. 
In addition to the calorimetric measurements, several high-temperature equilibrium studies involving aluminum carbide have been made, from which the heat of formation can be calculated. In each case the original calculations required estimates of the values of the thermal functions used for $\mathrm{Al}_{4} \mathrm{C}_{3}$ and, in some cases, for other compounds as well. Recent measurements of the heat capacity by Furukawa et al. [7] permit calculations now to be made using functions based on measurements over much of the temperature range of interest for $\mathrm{Al}_{4} \mathrm{C}_{3}$. In general, we consider the equilibrium studies to be less reliable than the best combustion measurements for calculating the heat of formation. The measured heat of formation and heat capacities can be used to correlate the equilibrium studies. Inconsistencies in the equilibrium data can possibly be used to detect errors of technique or interpretation of the equilibrium measurements. Such a study is presented by Furukawa et al.

The equilibrium studies will be briefly mentioned. Campbell [8] measured the activity of aluminum in $\mathrm{Al}_{4} \mathrm{C}_{3}$ at $920{ }^{\circ} \mathrm{C}$, from which he calculated the free energy of formation of aluminum carbide, $\Delta G f_{1193}^{\circ}=$ $-35.8 \mathrm{kcal} \mathrm{mole}{ }^{-1}$. Using thermodynamic data for $\mathrm{Al}_{4} \mathrm{C}_{3}$ based on the heat capacity measurements of Furukawa et al. [7] and recent tabulations of thermal functions for $\mathrm{Al}(\mathrm{g})$ and $\mathrm{C}(\mathrm{s})$ [9], we calculated $\Delta H f_{298}^{\circ}\left[\mathrm{Al}_{4} \mathrm{C}_{3}\right]=-51.2 \mathrm{kcal} \mathrm{mole}{ }^{-1}$ from Campbell's free energy of formation.

The vapor pressure of aluminum carbide has been measured approximately by Ruff [10] between 1500 and $2300^{\circ} \mathrm{K}$, by Chupka et al. [11] at $2100^{\circ} \mathrm{K}$, and by Meschi and Searcy [12] over the range 1500 to $1800^{\circ} \mathrm{K}$. In the measurement of Ruff the species in the vapor do not appear to be well defined and his pressures are much too bigh when compared with those of Chupka and of Meschi and Searcy. Chupka et al. found $p=6 \times 10^{-4} \mathrm{~atm}$, from which we can calculate $\Delta H f_{298}^{\circ}\left[\mathrm{Al}_{4} \mathrm{C}_{3}\right]=-91.5 \mathrm{kcal} \mathrm{mole} \mathrm{e}^{-1}$, assuming the only vapor species present to be $\mathrm{Al}(\mathrm{g})$. Taking from Meschi and Searcy the average vapor pressure, $p=4.2 \times 10^{-6}$ atm at $1600^{\circ} \mathrm{K}$, and assuming that vaporization occurred according to reaction (2) we calculate

$$
\mathrm{Al}_{4} \mathrm{C}_{3}(\mathrm{~s})=4 \mathrm{Al}(\mathrm{g})+3 \mathrm{C}(\mathrm{s})
$$

$\Delta H_{1600}=366.3 \mathrm{kcal} \mathrm{mole}{ }^{-1}$ and $\Delta H f_{298}^{\circ}\left[\mathrm{Al}_{4} \mathrm{C}_{3}\right]=-63.5$ kcal mole ${ }^{-1}$.

Equilibria in the system $\mathrm{Al}_{4} \mathrm{C}_{3}-\mathrm{N}_{2}$ were studied by Prescott and Hincke [13]. They assumed that the equilibrium was represented by eq (3),

$$
\mathrm{Al}_{4} \mathrm{C}_{3}(\mathrm{~s})+2 \mathrm{~N}_{2}(\mathrm{~g})=4 \mathrm{AlN}(\mathrm{s})+3 \mathrm{C}(\mathrm{s}) .
$$

Von Stackelberg et al. [14, 15] pointed out that the more probable reactions were reaction (4) in the nitrogen rich mixture and reaction (5) in the nitrogen lean mixtures and that a distinction could be drawn between these, which would lead to the energy of reaction (6).

$$
\begin{gathered}
\mathrm{Al}_{5} \mathrm{C}_{3} \mathrm{~N}(\mathrm{c})+2 \mathrm{~N}_{2}(\mathrm{~g})=5 \mathrm{AlN}(\mathrm{c})+3 \mathrm{C}(\mathrm{c}) \\
5 \mathrm{Al}_{4} \mathrm{C}_{3}(\mathrm{c})+2 \mathrm{~N}_{2}(\mathrm{~g})=4 \mathrm{Al}_{5} \mathrm{C}_{3} \mathrm{~N}(\mathrm{c})+3 \mathrm{C}(\mathrm{c}) \\
\mathrm{Al}_{4} \mathrm{C}_{3}(\mathrm{c})+\mathrm{AlN}(\mathrm{c})=\mathrm{Al}_{5} \mathrm{C}_{3} \mathrm{~N}(\mathrm{c}) .
\end{gathered}
$$

This manner of treating the data has been discussed by Satoh [16] and by Efimenko et al. [17].

If we use the results of the analysis by Efimenko et al., which gives $\Delta H_{298}=263.2 \mathrm{kcal} \mathrm{mole}{ }^{-1}$ for the enthalpy change of reaction (3), and apply $\Delta H f_{298}^{\circ}$ $[\mathrm{AlN}]=-76.0 \mathrm{kcal} \mathrm{mole}^{-1}$ recommended by Armstrong and Krieger [18], we find $\Delta H f_{298}^{\circ}\left[\mathrm{Al}_{4} \mathrm{C}_{3}\right]=$ $-40.8 \mathrm{kcal} \mathrm{mole}{ }^{-1}$.

Herstad [19] reported a measurement of equilibrium pressures of $\mathrm{Mg}$ vapor in reaction (7) near 1400 ${ }^{\circ} \mathrm{K}$, and calculation of the free energy of

$8 \mathrm{MgO}(\mathrm{s})+\mathrm{Al}_{4} \mathrm{C}_{3}(\mathrm{~s})=2 \mathrm{MgAl}_{2} \mathrm{O}_{4}(\mathrm{~s})+3 \mathrm{C}(\mathrm{s})+6 \mathrm{Mg}(\mathrm{g})$

formation of aluminum carbide from solid carbon and liquid aluminum at $1400{ }^{\circ} \mathrm{K} ; \Delta G f_{1400}^{\circ}=-220$ $\pm 1.5 \mathrm{kcal} \mathrm{mole}^{-1}$. Using this value and free energy functions for $\mathrm{Al}_{4} \mathrm{C}_{3}, \mathrm{Al}$, and $\mathrm{C}[7,9]$, we calculate $\Delta H f_{298}^{\circ}\left[\mathrm{Al}_{4} \mathrm{C}_{3}\right]=-58.5 \mathrm{kcal} \mathrm{mole}^{-1}$.

Equilibria in the system $\mathrm{Al}-\mathrm{O}-\mathrm{C}$ were studied at high temperatures and the vapor pressures of $\mathrm{CO}$ in this system were measured by Prescott and Hincke [20], Brunner [21], and Treadwell and Gyger [22]. These equilibrium studies were used to calculate the heat of formation of $\mathrm{Al}_{4} \mathrm{C}_{3}$ by various workers, before it was realized that the equilibria are complicated by the occurrence of aluminum oxycarbides [23]. More recent equilibrium studies by Cox and Pidgeon [24], by Motzfeldt [25], and by Franck [26] take into account the formation of $\mathrm{Al}_{4} \mathrm{O}_{4} \mathrm{C}$ and $\mathrm{Al}_{2} \mathrm{OC}$. However, no thermodynamic data have been measured for these compounds. The calculation of the heat of formation of $\mathrm{Al}_{4} \mathrm{C}_{3}$ from the observed equilibrium data requires estimates of the thermal functions of $\mathrm{Al}_{4} \mathrm{O}_{4} \mathrm{C}$ and $\mathrm{Al}_{2} \mathrm{OC}$, and therefore, we do not consider these equilibria further in this paper.

\section{Experimental Procedure}

\subsection{Materials}

The aluminum carbide sample was supplied by the Aluminum Company of America Research Laboratories. It was prepared by heating a stoichiometric mixture of aluminum and lampblack in an argon atmosphere at $1800{ }^{\circ} \mathrm{C}$. Prior to the present work, this sample had been used for high- and lowtemperature heat capacity measurements at the National Bureau of Standards [7]. Specimens from the original sample were spectrochemically and chemically analyzed. After the heat capacity measurements, specimens were again chemically analyzed. The results from the analyses are given in table 1. 
TABLE 1. (a) Qualitative spectrochemical analysis of aluminum carbide sample

\begin{tabular}{|c|c|c|c|}
\hline Element & Percent & Element & Percent \\
\hline $\begin{array}{l}\mathrm{Ag} \\
\mathrm{Al} \\
\mathrm{Ca} \mathrm{n} \\
\mathrm{Cr} \\
\mathrm{Cu} \\
\mathrm{Fe} \\
\mathrm{Mg}\end{array}$ & $\begin{array}{l}\stackrel{?}{>} 10 \\
0.0001-0.001 \\
.001-.01(?) \\
.001-.01 \\
.1-1.0 \\
.001-0.01\end{array}$ & $\begin{array}{l}\mathrm{Mn} \\
\mathrm{Ni} \\
\mathrm{Si} \\
\mathrm{Ti} \\
\mathrm{V} \\
\mathrm{Z}\end{array}$ & $\begin{array}{l}0.0001-0.001 \\
.001-.01 \\
.01-.1 \\
.001-.01 \\
.01-.1 \\
.001-.01\end{array}$ \\
\hline
\end{tabular}

(b) Quantitative chemical analyses of aluminum carbide sample

\begin{tabular}{|c|c|c|c|c|c|c|}
\hline \multirow{2}{*}{ Component } & \multicolumn{6}{|c|}{ Percent by weight } \\
\hline & 1a & $1 \mathrm{~b}$ & $1^{\prime}$ & 2 & $2^{\prime}$ & 3 \\
\hline $\begin{array}{l}\mathrm{Al}_{4} \mathrm{C}_{3} \\
\mathrm{Free} \mathrm{Al} \\
\text { Free } \mathrm{C} \\
\mathrm{AlN} \\
\mathrm{Al}_{2} \mathrm{O}_{3} \\
\mathrm{Fe}\end{array}$ & $\begin{array}{r}94.9 \\
1.2 \\
0.9 \\
1.4 \\
2.0\end{array}$ & $\begin{array}{r}94.8 \\
1.3 \\
0.7 \\
1.3 \\
2.0\end{array}$ & $\begin{array}{l}94.61 \\
1.25 \\
0.8 \\
1.35 \\
1.99\end{array}$ & $\begin{array}{l}94.8 \\
1.0 \\
1.0 \\
1.3 \\
2.2 \\
0.06\end{array}$ & $\begin{array}{r}94.46 \\
1.00 \\
1.00 \\
1.29 \\
2.19 \\
0.06\end{array}$ & \\
\hline Total & 100.4 & 100.1 & 100.00 & 100. 36 & 100.00 & \\
\hline Total C.. & 24.65 & 24.43 & 24.48 & 24.73 & 24.64 & 24.57 \\
\hline
\end{tabular}

The spectrochemical analysis was performed in the Spectrochemical Section at the National Bureau of Standards. The quantitative analyses $1 \mathrm{a}, 1 \mathrm{~b}, 2$, and 3 were made in the Analysis and Purification Section using methods previously described [7]. Analyses $1 \mathrm{a}$ and $1 \mathrm{~b}$ were made on two specimens before any heat capacity measurements were made. Analyses 2 and 3 were made on two specimens after the sample had been used for high temperature and low temperature heat capacity studies. The fact that the chemical analyses total slightly more than 100 percent may be caused by uncertainties in the analytical methods and small inhomogeneities in the sample. Analysis $1^{\prime}$ is the average of analyses 1a and $1 \mathrm{~b}$, normalized to 100 percent. Analysis 2' is the same as analysis 2 , normalized to 100 percent. Analysis 3 was an independent measurement of total carbon, made by combustion of the sample and collection of carbon dioxide as for an organic compound. It was carried out because total carbon dioxide in the product gases was to be used as a measure of the amount of reaction occurring in the calorimetric experiments. The total carbon as listed in column 7 is in excellent agreement with the average of the total carbon in the normalized analyses, columns 4 and 6 , but is less than the total carbon calculated from the actual results of these analyses.

The oxygen used in these experiments was of high purity, specified by the manufacturer to contain impurities not exceeding 0.005 percent. Although further purification was probably not necessary for this gas, the oxygen was passed over copper oxide heated to $500{ }^{\circ} \mathrm{C}$ to oxidize combustible impurities and through successive columns of ascarite and magnesium perchlorate to remove carbon dioxide and moisture.

\subsection{Combustion Experiments}

The samples were burned in a Dickinson-type calorimeter [27]. The combustion bomb was a commercial calorimeter bomb made of type 20 corrosion resistant alloy steel and equipped with platinumiridium inlet tube and electrodes. A platinum-iridium support loop, approximately one inch in diameter, was attached to the lower end of the inlet tube.

The combustions were conducted under $30 \mathrm{~atm}$ of oxygen. In order to remove the air, the bomb was filled with 10 to $15 \mathrm{~atm}$ of oxygen for three times before being filled to the final pressure. The samples were ignited with a fuse wire for which the ignition energy amounted to $22 \mathrm{~J}$.

The definition, $1 \mathrm{cal}=4.184 \mathrm{~J}$, was used for expressing the results in calories. All atomic weights were taken from the 1961 Table of Atomic Weights based on carbon 12, adopted by the International Union of Pure and Applied Chemistry [28].

The calorimeter was calibrated with benzoic acid, National Bureau of Standards Sample 39i, which has a certified heat of combustion of $26,434 \mathrm{~J} \mathrm{~g}^{-1}$ (weight in vacuo).

We found it necessary to use different supports for the samples in the calibration experiments and in the aluminum carbide combustions. The benzoic acid pellets were weighed and burned in a small platinum crucible (about $7.5 \mathrm{~g}$ ). The powdered aluminum carbide samples were weighed in small platinum pans, made from 0.004-in.-thick foil. The samples were burned in these containers on aluminum oxide disks, $0.062 \mathrm{in}$. thick by $1.25 \mathrm{in}$. diam. In the bomb the disks were supported on the platinum-iridium loop described above. It was found that a platinum support with a low enough heat capacity to allow complete combustion of benzoic acid melts when aluminum carbide burns on it. On the other hand, incomplete combustion of the benzoic acid occurs if the support is massive enough to prevent melting during the aluminum carbide combustions. The difference is attributed to the fact that most of the heat from a benzoic acid combustion is carried away from the reaction zone by the products of combustion, which are all gases. On the other hand, in the aluminum carbide combustions some of the solid product, aluminum oxide, is in contact with the sample support and retains a large amount of the heat in this location. In all cases the combustion of the carbide was greater than 99.5 percent complete.

The alumina disk container was weighed before and after each aluminum carbide combustion experiment. During the experiment, the disk cracked but remained on the supporting loop. As an extra precaution, the base of the combustion bomb was covered with alumina disks so that the bomb could be cleaned easily if the container disk had shattered during the combustion.

$\mathrm{A}$ preliminary test of the behavior of the $\mathrm{Al}_{4} \mathrm{C}_{3}$ sample on exposure to air showed that a gain in weight occurred, which was very gradual at first, and then became increasingly rapid. On the other hand, a sample kept in a desiccator showed no weight 
change in the same interval of time. This test, which extended over an interval of 2 months, showed that if, after opening the sealed vial, it was stored in a desiccator, the aluminum carbide could be handled in air for the short time necessary to weigh the combustion sample, and prepare the bomb for a heat measurement, without detriment to the sample. In another preliminary experiment the aluminum carbide was tested for possible reaction in the bomb prior to ignition. A weighed sample was placed in the bomb and all process steps were conducted up to the point of ignition. After $4 \mathrm{hr}$, the sample was reweighed. No significant weight increase was observed.

The standard calorimeter for the calibration experiments consisted of the calorimeter vessel with stirrer and water, the platinum resistance thermometer, and the combustion bomb with its electrical connections, fuse, platinum crucible, an alumina disk sample support for aluminum carbide, $30 \mathrm{~atm}$ of oxygen, $1 \mathrm{ml}$ water, and five alumina disks covering base of the bomb. The water and calorimeter vessel, not including lid, weighed $3670 \mathrm{~g}$. The results for seven calibration experiments are given in table 2 .

Table 2. Calibration experiments

\begin{tabular}{|c|c|c|c|c|c|c|}
\hline Experiment No. & $m_{s}$ & $\Delta R_{c}$ & $f$ & $q$ & $\Delta e_{i}$ & $E_{s}$ \\
\hline $\begin{array}{l}15 \\
17 \\
21 \\
22\end{array}$ & $\begin{array}{c}g \\
1.002313 \\
1.000229 \\
1.001456 \\
1.000091 \\
1.001660 \\
1.001504 \\
1.000912\end{array}$ & $\begin{array}{c}\text { Ohms } \\
0.191495 \\
.191044 \\
.191300 \\
.191031 \\
.191317 \\
.191374 \\
.191257\end{array}$ & $\begin{aligned} & \times 10^{6} \\
&-134.25 \\
&-129.73 \\
&-129.13 \\
&-143.38 \\
&-134.58 \\
&-140.98 \\
&-139.41\end{aligned}$ & $\begin{array}{c}J \\
22.24 \\
22.30 \\
22.30 \\
23.20 \\
22.30 \\
22.30 \\
22.30\end{array}$ & $\begin{array}{c}J \text { ohm-1 } \\
15.5 \\
16.3 \\
16.4 \\
14.1 \\
15.5 \\
14.5 \\
14.7\end{array}$ & $\begin{array}{c}J o h m^{-1} \\
138441.0 \\
138479.5 \\
138464.4 \\
138474.1 \\
138480.3 \\
138417.7 \\
138420.5\end{array}$ \\
\hline
\end{tabular}

The calibration experiments were interspersed with measurements on aluminum carbide. In table 2 the columns listed beginning on the left, give the experiment number; the mass (weight in vacuo) of benzoic acid in grams, $m_{s}$; the corrected resistance thermometer change, $\Delta R_{c}$; the term $f$ in the factor $1+f$ used to convert the standard energy of combustion of the benzoic acid to actual bomb conditions; the correction for ignition energy and nitric acid formation, $q$; the correction to the energy equivalent of the calorimeter to bring it to that of the standard calorimeter system, $\Delta e_{i}$; and the calculated energy equivalent of the standard calorimeter, $E_{s}$. Seven experiments led to an energy equivalent of $138453.9 \mathrm{~J} \mathrm{ohm}^{-1}$ with a standard deviation of the mean of $10.4 \mathrm{~J} \mathrm{ohm}^{-1}$.

The standard calorimeter for the experiments with aluminum carbide differed from that in the calibration experiments only in the omission of water from the bomb in the aluminum carbide experiments.

\subsection{Examination of the products of the combustion}

The products of combustion of the aluminum carbide were examined to determine the quantities of carbon dioxide and nitrogen dioxide formed in the reaction, and to characterize the solid combustion products. Qualitative tests on the gaseous products for NO [29] and CO [30] were negative. The carbon dioxide formed in each experiment was measured by absorption in Ascarite [31]. The nitrogen dioxide formed was determined by absorption on specially purified manganese dioxide [32].

A semi-schematic diagram of the analytical train is given in figure 1 . Both the apparatus and

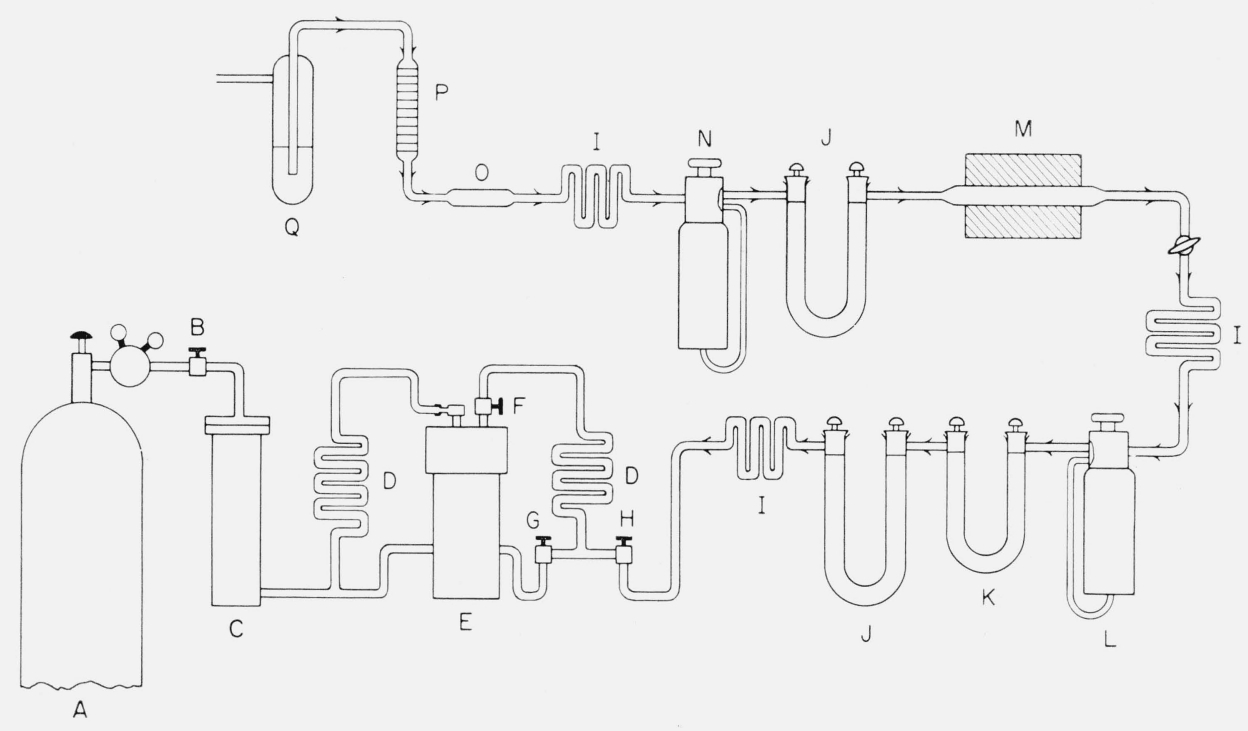

Figure 1. Train for analysis of bomb gases

(A) Cylinder of high-purity nitrogen, (B) microregulating valve, (C) absorption tube containing Ascarite and magnesium perchlorate, (D) coiled copper tube, (E) combustion bomb, (F) bomb outlet valve, (G) bypass valve, (H) valve, (I) glass tubing coil, (J) drying tube, (K) nitrogen dioxide absorption tube, (L) and (N) carbon dioxide absorbers, (M) furnace, (O) guard tube containing magnesium perchlorate and Ascarite, (P) flowmeter, (Q) bubbler. 
analytical procedures are similar in many respects to those used by Prosen and Rossini [33]. $A$ is a cylinder of high-purity nitrogen under pressure. The nitrogen passes through a Monel tube, $C$, containing successive layers of Ascarite and magnesium perchlorate. The flow rate of the nitrogen is adjusted with the microregulating valve, $B$. The coiled copper tubes, $D$, lead to the inlet and outlet valves on the combustion bomb, $E$. The valves, $F$ and $H$, are used to control the flow rate of gases from the combustion bomb. When the inlet and outlet valves to the bomb are closed, and valves $G$ and $H$ are open, the train may be flushed with nitrogen, bypassing the combustion bomb. This is often found useful when checking for leaks immediately prior to an analysis. The tube, $J$, contains magnesium perchlorate for removal of moisture. Tube $K$, containing manganese dioxide backed by magnesium perchlorate, absorbs nitrogen dioxide. Carbon dioxide formed in the combustion reaction is absorbed in tube $L$, which contains Ascarite backed by magnesium perchlorate. Any carbon monoxide formed in the combustion is converted to carbon dioxide in the furnace, $M$, and is then dried over magnesium perchlorate in $J$, and absorbed in the tube $N$, which also contains Ascarite backed by magnesium perchlorate. The furnace, $M$, is a tube wound with nichrome and containing a Vycor tube filled with copper oxide which is kept at $500{ }^{\circ} \mathrm{C}$. Tube $O$ contains successive layers of magnesium perchlorate and Ascarite to prevent back diffusion of carbon dioxide and moisture from the air. $P$ is a float-type flowmeter and $Q$ is a bubbler.

During the period immediately preceding the combustion experiment, the absorption tubes, $K, L$, and $N$, are flushed, filled with nitrogen, and weighed. The tubes are replaced in the train for the analysis. Immediately after the experiment, the valve, $F$, is attached to the outlet valve on the bomb. After inserting the bomb, the train is flushed with nitrogen by way of the bypass around the bomb for about $10 \mathrm{~min}$ and then valve $G$ is closed. Valve $H$ is opened and the gases are released from the bomb at a rate of about $200 \mathrm{ml} \mathrm{min}{ }^{-1}$. When the pressure in the bomb reaches $1 \mathrm{~atm}$, the inlet valve is opened and nitrogen is passed through the bomb at the foregoing rate for $1 \mathrm{hr}$. The absorption tubes are removed from the train, cleaned, and reweighed. The true mass of the absorbed carbon dioxide was calculated using the method outlined by Rossini [34].

The reproducibility of the weighings of the absorption tubes was 0.0001 to $0.0005 \mathrm{~g}$. In blank experiments in which the same quantity of nitrogen was passed through as in an analysis, no weight changes could be detected outside of these limitations. The accuracy of these analytical procedures was checked from time-to-time by determining the quantity of carbon dioxide produced from the combustion of a sample of benzoic acid. These checks indicated that the analyses were accurate to within \pm 0.01 percent for absorption of $3.8 \mathrm{~g}$ of carbon dioxide. In the aluminum carbide experiments, the mass of carbon dioxide collected was about $0.77 \mathrm{~g}$. The amount of nitrogen dioxide collected varied from 1.5 to $4.0 \mathrm{mg}$.

\subsection{Identification of Solid Product}

The solid product from the combustions was characterized by x-ray diffraction on the basis of patterns maintained at the National Bureau of Standards and those published by Newsome et al. [35]. In each experiment a large fraction of the product aluminum oxide was deposited in extremely finely divided form on the wall of the bomb. The remaining alumina, in the form of a fused mass, was on the reaction disk. The alumina on the disk was alpha alumina only, and that on the bomb wall was a different crystalline form, similar to delta alumina. Because all of the alpha aluminum oxide remained on the reaction disk, it was possible to separate the two alumina phases and determine the quantity of each obtained in an experiment.

The $x$-ray data for the transition ${ }^{3}$ alumina obtained in the present study are given in table 3, along with the data obtained by Rooksby [36] and Stumpf [35] for delta alumina. The pattern given by Stumpf was obtained from delta alumina prepared by calcination of pure alpha alumina monohydrate (Böhmite). He has pointed out that delta alumina prepared by this method exhibits slightly diffuse diffraction lines indicative of small crystal size or crystal imperfection [37]. Rooksby investigated several ways of preparing delta alumina and obtained the pattern given here from alumina prepared by calcination of ammonium aluminum sulfate with ammonium molybdate at $950{ }^{\circ} \mathrm{C}$. He found that a more crystalline delta alumina resulted from this method than from the calcination of Böhmite. It will be seen that there are differences between the Rooksby and Stumpf patterns. Even with the variations in the diffraction patterns observed, it is generally acknowledged that delta alumina is a definite crystalline form. However, until the situation is further clarified, a choice cannot be made as to which is the better pattern.

The $\mathrm{x}$-ray pattern for the transition alumina found in this study is more nearly similar to the Rooksby pattern than to that reported by Stumpf. However, it has some features in common with the Stumpf pattern which are lacking in Rooksby's. Each pattern has some distinctive lines.

Foster et al. [23] observed a delta-like alumina in a study of the equilibrium diagram for the $\mathrm{Al}_{4} \mathrm{C}_{3}-\mathrm{Al}_{2} \mathrm{O}_{3}$ system. Newsome et al. [35] report that delta alumina can be prepared by fusion together of alumina and aluminum nitride. This indicates that delta alumina is stabilized by nitrogen. These earlier studies suggest that the formation of the delta alumina in this study probably is promoted by the nitrogen and carbon in the aluminum carbide sample.

${ }^{3}$ Newsome et al. [35] designate crystalline forms of alumina, other than alpha alumina, as transition aluminas. 
TABLE 3. X-ray data for finely divided aluminum oxide formed in the combustion bomb

\begin{tabular}{|c|c|c|c|c|c|c|}
\hline \multirow{2}{*}{\multicolumn{3}{|c|}{ Present work }} & \multicolumn{4}{|c|}{ Delta $\mathrm{Al}_{2} \mathrm{O}_{3}$} \\
\hline & & & \multicolumn{2}{|c|}{ Rooksby [36] } & \multicolumn{2}{|c|}{ Stumpf [35] } \\
\hline$\theta^{\circ}$ & $d$ & I & d & I & d & I \\
\hline $\operatorname{deg}$ & ${ }^{\circ} A$ & & $\begin{array}{l}\circ A \\
7.97 \\
6.58\end{array}$ & $\begin{array}{r}8 \\
10\end{array}$ & ${ }^{\circ} \mathrm{A}$ & \\
\hline 17. 42 & 5. 08 & 11 & 5. 07 & 20 & 5. 02 & 30 \\
\hline 21.82 & 4.06 & 12 & 4.05 & 20 & $\begin{array}{l}4.55 \\
4.07\end{array}$ & $\begin{array}{l}30 \\
20\end{array}$ \\
\hline $\begin{array}{l}23.60 \\
25.02 \\
26.09 \\
27.06 \\
27.64\end{array}$ & $\begin{array}{l}\text { 3. } 76 \\
\text { 3. } 55 \\
\text { 3. } 412 \\
\text { 3. } 292 \\
\text { 3. } 224\end{array}$ & $\begin{array}{r}4 \\
6 \\
7 \\
12 \\
5\end{array}$ & $\begin{array}{l}\text { 3. } 56 \\
3.40 \\
3.28 \\
3.21\end{array}$ & $\begin{array}{r}7 \\
10 \\
15 \\
10\end{array}$ & & \\
\hline $\begin{array}{l}29.26 \\
30.49\end{array}$ & $\begin{array}{l}3.049 \\
2.929\end{array}$ & $\begin{array}{l}7 \\
3\end{array}$ & 3. 03 & 10 & & \\
\hline 31.21 & 2.863 & 6 & & & 2.87 & 40 \\
\hline $\begin{array}{l}31.55 \\
32.04\end{array}$ & $\begin{array}{l}2.833 \\
2.791\end{array}$ & $\begin{array}{r}8 \\
31\end{array}$ & 2. 783 & 30 & & \\
\hline 32.74 & 2. 732 & 18 & 2. 737 & 30 & 2. 73 & 80 \\
\hline $\begin{array}{l}34.45 \\
35.11\end{array}$ & $\begin{array}{l}2.601 \\
2.553\end{array}$ & $\begin{array}{r}47 \\
8\end{array}$ & 2.593 & 70 & 2.58 & 30 \\
\hline $\begin{array}{l}36.54 \\
37.65\end{array}$ & $\begin{array}{l}2.457 \\
2.387\end{array}$ & $\begin{array}{l}62 \\
19\end{array}$ & 2.457 & 70 & 2.43 & 60 \\
\hline 38. 96 & 2. 309 & 36 & 2. 311 & 40 & & \\
\hline $\begin{array}{l}39.44 \\
39\end{array}$ & $\begin{array}{l}2.282 \\
2\end{array}$ & 36 & 2.277 & 30 & 2.28 & 40 \\
\hline 41. 69 & $\begin{array}{l}2.168 \\
2.164\end{array}$ & $\begin{array}{l}55 \\
13\end{array}$ & 2.156 & 25 & & \\
\hline 44.72 & 2.024 & 3 & & & & \\
\hline 45. 70 & 1. 983 & 69 & 1. 989 & 70 & 1.99 & 80 \\
\hline 46.35 & 1. 957 & 37 & 1. 950 & 65 & 1.95 & 30 \\
\hline 50.66 & 1.800 & 4 & 1.793 & 7 & 1.91 & 20 \\
\hline $\begin{array}{l}53.84 \\
569\end{array}$ & 1. 701 & 3 & 1. 701 & 4 & 1.80 & 20 \\
\hline 56.99 & 1.614 & 12 & 1.616 & 10 & & \\
\hline 57.41 & 1. 603 & 11 & 1. 602 & 15 & & \\
\hline 59. 94 & 1. 541 & 11 & 1.543 & 10 & 1.54 & 40 \\
\hline 61.52 & $\begin{array}{l}1.020 \\
1.506\end{array}$ & 20 & 1.507 & 20 & 1.51 & 30 \\
\hline & & & & & 1.49 & 40 \\
\hline 63.57 & 1. 462 & 5 & 1. 462 & 8 & 1.45 & 30 \\
\hline 64.78 & 1. 437 & 3 & & & & \\
\hline $\begin{array}{l}65.87 \\
66.60\end{array}$ & $\begin{array}{l}\text { 1. } 418 \\
1.402\end{array}$ & $\begin{array}{r}9 \\
60\end{array}$ & 1.407 & 60 & 1.40 & 60 \\
\hline 67.13 & 1. 393 & 100 & 1. 392 & 100 & $\begin{array}{l}\text { 1. } 39 \\
1.29\end{array}$ & 100 \\
\hline & & & & & 1.26 & 10 \\
\hline $\begin{array}{l}76.23 \\
77.16\end{array}$ & $\begin{array}{l}1.247 \\
1.235\end{array}$ & $\begin{array}{l}4 \\
6\end{array}$ & $\begin{array}{l}1.250 \\
1.238\end{array}$ & $\begin{array}{l}4 \\
9\end{array}$ & & \\
\hline & & & 1.180 & 4 & & \\
\hline 84. 92 & 1.141 & 10 & & & 1.14 & 20 \\
\hline 85.20 & 1. 137 & 8 & 1.134 & 10 & & \\
\hline
\end{tabular}

\section{Results}

\subsection{Heat Measurements}

In table 4 are listed $m_{s}$, the mass of sample; $m\left(\mathrm{CO}_{2}\right)$, the mass of $\mathrm{CO}_{2} ; \Delta R_{c}$, the corrected resistance thermometer change; $\Delta e_{2}$, the correction for the deviation of this calorimeter from the standard calorimeter; and $-\Delta U_{B}$, the observed energy of reaction at $28{ }^{\circ} \mathrm{C}$.

These include corrections for the combustion of impurities on the basis of analysis 2 (table $1 \mathrm{~b}$ ). In making these corrections, it was assumed that the completeness of combustion of the impurities was the same as that for the aluminum carbide sample, which was calculated from the ratio of the observed to expected amounts of $\mathrm{CO}_{2}$ formed. $q_{1}$ is the ignition energy; $q_{2}$, the correction to standard state; and $q_{3}$, the correction to $25^{\circ} \mathrm{C}$.
TABLE 4. Heat measurements on aluminum carbide samples

\begin{tabular}{|c|c|c|c|c|c|}
\hline $\begin{array}{c}\text { Experiment } \\
\text { No. }\end{array}$ & $m_{s}$ & $m\left(\mathrm{CO}_{2}\right)$ & $\Delta R_{c}$ & $\Delta e_{2}$ & $\begin{array}{l}-\Delta U_{B} \\
28^{\circ} \mathrm{C}\end{array}$ \\
\hline $\begin{array}{l}10 \\
11 \\
12 \\
13 \\
18 \\
19 \\
20\end{array}$ & $\begin{array}{l}g \\
0.852498 \\
.851387 \\
.851040 \\
.849675 \\
.851301 \\
.848726 \\
.854470 \\
.850351\end{array}$ & $\begin{array}{r}g \\
0.771016 \\
.770745 \\
.764905 \\
.765961 \\
.766513 \\
.765632 \\
.771409 \\
.767780\end{array}$ & $\begin{array}{c}\text { Ohm } \\
0.178892 \\
.178673 \\
.178031 \\
.178751 \\
.178648 \\
.177593 \\
.179115 \\
.179008\end{array}$ & $\begin{array}{r}J \text { ohm-1 } \\
-27.5 \\
-27.5 \\
-27.5 \\
-29.5 \\
-28.8 \\
-29.8 \\
-29.4 \\
-29.1\end{array}$ & $\begin{array}{l}J \\
24763.4 \\
24733.1 \\
2464.2 \\
24743.5 \\
24729.4 \\
2458.2 \\
24793.9 \\
24779.2\end{array}$ \\
\hline
\end{tabular}

To $\Delta U_{B}$ were applied corrections listed in table 5 .

TABLE 5. Corrections to combustion data on aluminum carbide

\begin{tabular}{|c|c|c|c|c|c|c|c|c|}
\hline $\begin{array}{l}\text { Experi- } \\
\text { ment No. }\end{array}$ & $q_{\mathrm{A} \backslash \mathrm{N}}$ & $q_{\mathrm{A} 1}$ & $q_{\mathrm{Fe}}$ & $q_{\mathrm{C}}$ & $q_{1}$ & $q_{2}$ & $q_{3}$ & $\Sigma_{\text {corr }}$ \\
\hline $\begin{array}{l}10 \\
11 \\
12 \\
13 \\
16 \\
19 \\
20\end{array}$ & $\begin{array}{c}J \\
-137.3 \\
-136.7 \\
-136.6 \\
-137.5 \\
-136.7 \\
-137.1 \\
-136.0 \\
-135.5\end{array}$ & $\begin{array}{c}J \\
-264.4 \\
-264.4 \\
-262.3 \\
-262.7 \\
-262.9 \\
-262.6 \\
-264.6 \\
-263.3\end{array}$ & $\begin{array}{l}J \\
-3.8 \\
-3.8 \\
-3.7 \\
-3.7 \\
-3.7 \\
-3.7 \\
-3.8 \\
-3.7\end{array}$ & $\begin{array}{c}J \\
-279.6 \\
-279.5 \\
-277.5 \\
-277.9 \\
-278.0 \\
-277.7 \\
-279.8 \\
-278.5\end{array}$ & $\begin{aligned} & J \\
&-22.0-22.0 \\
&-22.0 \\
&-22.0 \\
&-22.0 \\
&-22.0 \\
&-22.0 \\
&-22.0\end{aligned}$ & $\begin{array}{l}J \\
5.3 \\
5.3 \\
5.2 \\
5.0 \\
5.1 \\
5.2 \\
5.0 \\
5.0\end{array}$ & $\begin{aligned} & J \\
&-4.5-4.5 \\
&-4.4 \\
&-4.5 \\
&-4.5 \\
&-4.5 \\
&-4.5 \\
&-4.5\end{aligned}$ & $\begin{array}{c}J \\
-706.3 \\
-705.6 \\
-701.3 \\
-703.3 \\
-702.7 \\
-702.4 \\
-705.7 \\
-702.5\end{array}$ \\
\hline
\end{tabular}

In making the correction for the combustion of AlN it was assumed that the AlN burned according to the reactions (8) and (9).

$$
\begin{aligned}
& \mathrm{AlN}(\mathrm{s})+7 / 4 \mathrm{O}_{2}(\mathrm{~g}) \rightarrow \frac{1}{2} \mathrm{Al}_{2} \mathrm{O}_{3}(\mathrm{~s})+\mathrm{NO}_{2}(\mathrm{~g}) \\
& \mathrm{AlN}(\mathrm{s})+3 / 4 \mathrm{O}_{2}(\mathrm{~g}) \rightarrow \frac{1}{2} \mathrm{Al}_{2} \mathrm{O}_{3}(\mathrm{~s})+\frac{1}{2} \mathrm{~N}_{2}(\mathrm{~g})
\end{aligned}
$$

Since the $\mathrm{NO}_{2}$ formed was measured, it was possible to obtain the amount of AlN burned in reaction (9) by difference. In both cases, the energies of reaction were calculated using the heats of formation of AlN [18], $\mathrm{Al}_{2} \mathrm{O}_{3}$ [3], and $\mathrm{NO}_{2}$ [38].

Corrections for the energies of combustion of the remaining impurities were made assuming the following reactions, using heat data from the literature $[3,38]$.

$$
\begin{aligned}
& \mathrm{Al}(\mathrm{s})+\frac{3}{4} \mathrm{O}_{2}(\mathrm{~g}) \rightarrow \frac{1}{2} \mathrm{Al}_{2} \mathrm{O}_{3}(\mathrm{~s}) \\
& \mathrm{C}(\mathrm{s})+\mathrm{O}_{2}(\mathrm{~g}) \rightarrow \mathrm{CO}_{2}(\mathrm{~g}) \\
& \mathrm{Fe}(\mathrm{s})+\frac{3}{4} \mathrm{O}_{2}(\mathrm{~g}) \rightarrow \frac{1}{2} \mathrm{Fe}_{2} \mathrm{O}_{3}(\mathrm{~s})
\end{aligned}
$$

The corrections for the deviation of the gases from the ideal gas law were made according to the procedure outlined by Prosen [39].

The corrected energies of combustion, which are the energies of combustion of aluminum carbide in the original sample, are given in column 2 of table 6 . 
TABLE 6. Heat of combustion of $\mathrm{Al}_{4} \mathrm{C}_{3}$

\begin{tabular}{|c|c|c|c|c|c|c|}
\hline $\begin{array}{c}\text { Experi- } \\
\text { ment No. }\end{array}$ & $-q \mathrm{Al}_{4} \mathrm{C}_{3}$ & $\begin{array}{c}\mathrm{CO}_{2} \\
\text { (obs/calc) }\end{array}$ & $\frac{\mathrm{Al}_{2} \mathrm{O}_{3}}{\alpha+\delta}$ & $m_{s}^{\prime}$ & $\begin{aligned}- & \Delta U_{298}^{\circ} \\
& \left(\mathrm{Al}_{4} \mathrm{C}_{3}\right) \\
& (\mathrm{obs})\end{aligned}$ & $\begin{array}{r}-\Delta U_{298}^{\circ} \\
\left(\mathrm{Al}_{4} \mathrm{C}_{3}\right) \\
(\text { to } \alpha- \\
\left.\mathrm{Al}_{2} \mathrm{O}_{3}\right)\end{array}$ \\
\hline $\begin{array}{l}10 \\
11 \\
12 \\
13 \\
16 \\
18 \\
19 \\
20\end{array}$ & $\begin{array}{c}J \\
24057.1 \\
24027.5 \\
23942.4 \\
24040.2 \\
24026.7 \\
23880.8 \\
24088.2 \\
24076.7\end{array}$ & $\begin{array}{r}1.0018 \\
1.0027 \\
0.9956 \\
.9985 \\
.9973 \\
.9992 \\
1.0000 \\
1.0001\end{array}$ & $\begin{array}{l}0.768 \\
.641 \\
.456 \\
.475 \\
.471 \\
.517 \\
.517 \\
.472\end{array}$ & $\begin{array}{c}g \\
0.806580 \\
.806293 \\
.800176 \\
.801280 \\
.801857 \\
.800936 \\
.806976 \\
.803183\end{array}$ & $\begin{array}{c}J g-1 \\
29826.1 \\
29800.0 \\
29922.0 \\
30002.2 \\
29963.8 \\
29816.1 \\
29850.0 \\
29976.6\end{array}$ & $\begin{array}{c}J q^{-1} \\
29947.6 \\
29900.6 \\
29993.6 \\
30076.8 \\
30037.7 \\
29897.2 \\
29931.1 \\
30050.7\end{array}$ \\
\hline \multicolumn{5}{|c|}{$\begin{array}{l}\text { Mean and standard dev. of the mean, } \mathrm{J} \mathrm{g}^{-1} \text { : } \\
\text { Mean and std. dev. of the mean, keal mole-1: }\end{array}$} & $\begin{array}{l}29894.6 \\
\pm 30.6 \\
1028.69 \\
\quad \pm 1.0\end{array}$ & $\begin{array}{r}29979.4 \\
\pm 25.4 \\
1031.5 \\
\pm 0.9\end{array}$ \\
\hline
\end{tabular}

The ratio of $\mathrm{CO}_{2}$ observed to that calculated from analysis 4 is shown in column 3. The observed fraction of delta phase in the alumina formed is given in column 4 . The mass of aluminum carbide burned, $m_{s}^{\prime}$, was calculated from the observed mass of $\mathrm{CO}_{2}$, corrected for the mass of $\mathrm{CO}_{2}$ originating. from the combustion of the free carbon in the original sample. $m_{s}^{\prime}$ is considered to be the best measure of the amount of reaction that occurred, because the aluminum carbide was apparently not entirely homogeneous. The lack of homogeneity is suggested by the scatter in the values for $\mathrm{CO}_{2}$ (obs/calc). Values greater than 1.0 can only be accounted for if the percent carbon in the sample burned was greater than that calculated from analysis 4 , which showed the highest carbon content of all the analyses. The range of values of the ratio $\mathrm{CO}_{2}$ (obs/calc) is about halif the percentage range of values for carbon found in the several analyses of the aluminum carbide sample. The standard energy of combustion of aluminum carbide in $\mathrm{J} \mathrm{g}^{-1}$ based on $\mathrm{m}_{\mathrm{s}}^{\prime}$, but not corrected for variations observed in $\mathrm{Al}_{2} \mathrm{O}_{3}$ formed, is shown as $-\Delta U_{298}^{\circ}\left(\mathrm{Al}_{4} \mathrm{C}_{3}\right)$ in column 6 .

As shown in column 4, table 6 , delta aluminum oxide constituted a large fraction of the alumina formed in the combustion of the aluminum carbide. To obtain $\Delta H_{298.15}^{\circ}$ for the combustion of aluminum carbide to alpha alumina only, a correction was applied for the formation of delta alumina.

The energy difference between the delta and alpha aluminas was measured by means of solution calorimetry by Kleppa and Yokokawa. ${ }^{4}$ The experiments were carried out by dissolving aluminum oxide samples in a $\mathrm{PbO}-\mathrm{BaO}-\mathrm{B}_{2} \mathrm{O}_{3}$ melt at $705{ }^{\circ} \mathrm{C}$. The delta alumina samples used for these experiments were obtained from the combustion of the aluminum carbide in the experiments described in the present work. The alpha alumina studied was obtained from various sources. Some samples were made by heating the delta alumina at $1450{ }^{\circ} \mathrm{C}$, and other samples were of different origin. The solution energies for the alpha alumina from the different sources were in agreement. For the conversion of

${ }^{4}$ O. J. Kleppa and T. Yokokawa (Department of Chemistry and Institute for the Study of Metals, University of Chicago). This work is described in a Lette to the Editor submitted to the Journal of the American Chemicai Society. delta to alpha alumina (reaction 13), these investigators found a value of $\Delta H^{\circ}=-2.7 \pm 0.4 \mathrm{kcal}$ mole ${ }^{-1}$.

$$
\delta-\mathrm{Al}_{2} \mathrm{O}_{3}=\alpha-\mathrm{Al}_{2} \mathrm{O}_{3}
$$

The energy of combustion of aluminum carbide to alpha alumina only is $\Delta E_{298,15}=-1031.5 \pm 1.0$ keal mole ${ }^{-1}$. Conversion to the constant pressure process leads to $\Delta H_{298.15}=-1033.3 \pm 1.0 \mathrm{kcal} \mathrm{mole}^{-1}$. The uncertainty (1.0) is the square root of the sum of the squares of the standard deviation (0.9) in the combustion measurements and the uncertainty (0.4) in the correction for the conversion of delta alumina to alpha alumina.

\subsection{Heat of Formation of Aluminum Carbide}

Combining the heat of combustion for aluminum carbide with $\Delta H f_{298.15}\left[\mathrm{CO}_{2}\right]=-94.05 \pm 0.01 \mathrm{kcal}$ mole $^{-1}[38]$ and $\Delta H f^{\circ}{ }_{298.15}\left[\alpha-\mathrm{Al}_{2} \mathrm{O}_{3}\right]=-400.4 \pm 0.3$ keal mole ${ }^{-1}[3]$, we obtain $\Delta H f^{\circ}{ }_{298.15}\left[\mathrm{Al}_{4} \mathrm{C}_{3}\right]=-49.7$ $\pm 1.2 \mathrm{kcal} \mathrm{mole}^{-1}$.

The overall uncertainty $\left(1.2 \mathrm{kcal} \mathrm{mole}^{-1}\right)$ of the heat of formation of aluminum carbide is the square root of the sum of the squares of the uncertainty, $0.3 \mathrm{kcal} \mathrm{mole}^{-1}$, assigned to the heat of formation of alpha aluminum oxide; 0.01 keal mole $^{-1}$ for the uncertainty in the heat of formation of carbon dioxide; $1.0 \mathrm{kcal} \mathrm{mole}^{-1}$ found for the uncertainty in the heat of combustion of the aluminum carbide to alpha alumina only.

The authors thank Professor O. J. Kleppa and Dr. T. Yokokawa of the University of Chicago for carrying out the solution calorimetry experiments. The x-ray diffraction analyses were made by Howard Swanson of the Inorganic Materials Division of the National Bureau of Standards, and the chemical analyses were performed by Rolf Paulson of the Analytical Chemistry Division. Their assistance is also gratefully acknowledged.

This work was supported by the Advanced Research Projects Agency.

\section{References}

[1] A. Meichsner and W. A. Roth, Z. Elektrochem. 40, 19 (1934).

[2] W. A. Roth, Z. Elektrochem. 48, 267 (1942).

[3] A. D. Mah, J. Phys. Chem. 61, 1572 (1957).

[4] M. Berthelot, Compt. Rend. 132, 281 (1901); Ann. Chim. Phys. [7] 22, 464 (1901).

[5] L. Wöhler and K. Hofer, Z. anorg. u. allgem. Chem. 213, 249 (1933).

[6] N. Kameyama and F. Yoshida, Denki Kagaku, 12, 171 (1944).

[7] G. T. Furukawa, T. B. Douglas, W. G. Saba, and A. C. Victor, J. Res. NBS (Phys. and Chem.), publication pending.

[8] C. S. Campbell, Met. Soc. Conf. y, 412 (1962).

[9] W. H. Evans, J. Hilsenrath, and H. W. Woolley, private communication; G. T. Furukawa, M. L. Reilly, J. H. Piccirelli, T. B. Douglas, A. C. Victor, and A. R. Beaudoin, private communication; W. H. Evans, private communication. 
[10] O. Ruff, Z. Elektrochem. 24, 157 (1918)

[11] W. A. Chupka, J. Berkowitz, C. F. Giese, and M.G. Ingram, J. Phys. Chem. 62, 611 (1958).

[12] D. J. Meschi and A. W. Searcy, J. Phys. Chem. 63, 1175 (1959).

[13] C. H. Prescott and W. B. Hincke, J. Am. Chem. Soc. 50, 3228 (1928).

[14] M. von Stackelberg, E. Schnorrenberg, R. Paulus, and K. F. Spiess, Z. Physik. Chem. A175, 127 (1935).

[15] M. von Stackelberg and K. F. Spiess, Z. Physik. Chem. A175, 140 (1935)

[16] S. Satoh, Sci. Papers Inst. Phys. Chem. Research (Tokyo) 34, 50-59 (1938).

[17] J. Efimenko, R. F. Hampson, R. F. Walker, and T. B. Douglas, private communication.

[18] G. T. Armstrong and L. A. Krieger, private communication.

[19] K. Grjotheim, O. Herstad, and K. Stahl-Johannessen, Z. Anorg. u. allgem. Chem. 327, 267 (1964).

[20] C. H. Prescott, Jr., and W. B. Hincke, J. Am. Chem. Soc. 49, 2753 (1927).

[21] R. Brunner, Z. Elektrochem. 38, 55 (1932).

[22] W. D. Treadwell and A. Gyger, Helv. Chim. Acta 16, 1214 (1933).

[23] L. M. Foster, G. Long, and M. S. Hunter, J. Am. Ceram. Soc. 39, 1 (1956).

[24] J. H. Cox and L. M. Pidgeon, Can. J. Chem. 41, 671 (1963).

[25] K. Motzfeldt, Tek. Ukeblad, 1137 (1962).

[26] W. B. Frank, Aluminum Company of America, private communication.

[27] R. S. Jessup, Precise Measurement of Heat of Combustion with a Bomb Calorimeter, NBS Mono. 7 Feb. 26 , 1960 .

[28] A. E. Cameron and E. Wichers, J. Am. Chem. Soc. 84, 4175 (1962).
[29] A. A. Noyes and E. H. Swift, Qualitative Chemical Analysis of Inorganic Substances, p. 368, (The MacMillan Company, N.Y., 1942.)

[30] M. Shepherd, Anal. Chem. 19, 77 (1947).

[31] R. Goulden, Comprehensive Analytical Chemistry, ed. C. L. Wilson and D. W. Wilson, p. 412, (Elsevier Publ. Co., New York, N.Y., 1960).

[32] R. Belcher and G. Ingram, Anal. Chim. Acta 4, 401 (1950).

[33] E. J. Prosen and F. D. Rossini, J. Res. NBS 27, 289 (1941) RP1420.

[34] F. D. Rossini, ch. 4, Experimental Thermochemistry, ed. by F. D. Rossini (Interscience Publishers, Inc., New York, N.Y., 1956).

[35] J. W. Newsome, H. W. Heiser, H. S. Russell, and H. C. Stumpf, Aluminum Company of America, Alcoa Research Laboratories, Tech. Paper No. 10 (revised 1960), pp. 12, 35 .

[36] H. P. Rooksby, J. Appl. Chem. 8, 44 (1958).

[37] H. C. Stumpf, Aluminum Company of America, private communication.

[38] F. D. Rossini, D. D. Wagman, W. H. Evans, S. Levine, and I. Jaffe, Selected Values of Chemical Thermodynamic Properties, NBS Circ. 500 (U.S. Government Printing Office, Washington, D.C., 1952).

[39] E. J. Prosen, ch. 6, Experimental Thermochemistry, ed. F. D. Rossini (Interscience Publishers, Inc., New York, N.Y., 1956).

[40] Allah D. Mah, Heat of Formation of Aluminum Carbide, U.S. Bureau of Mines, Report of Investigations 6415, 1964 .

(Paper 68A6-315) 